\title{
CAG repeat polymorphisms in the androgen receptor and breast cancer risk in women: a meta-analysis of 17 studies
}

This article was published in the following Dove Press journal:

OncoTargets and Therapy

13 August 2015

Number of times this article has been viewed

\author{
Qixing Mao ${ }^{1-3, *}$ \\ Mantang Qiul-3,* \\ Gaochao Dong ${ }^{3}$ \\ Wenjie $\mathrm{Xia}^{1-3}$ \\ Shuai Zhangl,3 \\ Youtao $\mathrm{Xu}^{1,3}$ \\ Jie Wang ${ }^{3}$ \\ Yin Rong ${ }^{1,3}$ \\ Lin $X u^{1,3}$ \\ Feng Jiang ${ }^{1,3}$ \\ 'Department of Thoracic Surgery, \\ Nanjing Medical University Affiliated \\ Cancer Institute of Jiangsu Province, \\ ${ }^{2}$ Fourth Clinical College of Nanjing \\ Medical University, ${ }^{3}$ jiangsu Key \\ Laboratory of Molecular and \\ Translational Cancer Research, \\ Nanjing, People's Republic of China \\ *These authors contributed equally \\ to this work
}

Correspondence: Lin Xu; Feng Jiang Department of Thoracic Surgery, Nanjing Medical University Affiliated Cancer Institute of Jiangsu Province, Baiziting 42, Nanjing 210009, People's Republic of China

Tel +862583284700

Fax +862583641062

Email xulin83cn@gmail.com;

zengnljf@hotmail.com

\begin{abstract}
The association between polymorphic CAG repeats in the androgen receptor gene in women and breast cancer susceptibility has been studied extensively. However, the conclusions regarding this relationship remain conflicting. The purpose of this meta-analysis was to identify whether androgen receptor CAG repeat lengths were related to breast cancer susceptibility. The MEDLINE, PubMed, and EMBASE databases were searched through to December 2014 to identify eligible studies. Data and study quality were rigorously assessed by two investigators according to the Newcastle-Ottawa Quality Assessment Scale. The publication bias was assessed by the Begg's test. Seventeen eligible studies were included in this meta-analysis. The overall analysis suggested no association between CAG polymorphisms and breast cancer risk (odds ratio [OR] 1.031, 95\% confidence interval [CI] 0.855-1.245). However, in the subgroup analysis, we observed that long CAG repeats significantly increased the risk of breast cancer in the Caucasian population (OR 1.447, 95\% CI 1.089-1.992). Additionally, the risk was significantly increased in Caucasian women carrying two alleles with CAG repeats $\geq 22$ units compared with those with two shorter alleles (OR 1.315, 95\% CI 1.014-1.707). These findings suggest that long CAG repeats increase the risk of breast cancer in Caucasian women. However, larger scale case-control studies are needed to validate our results.
\end{abstract}

Keywords: androgen, CAG repeat polymorphism, women, breast cancer, risk, meta-analysis

\section{Introduction}

Breast cancer is the most common cause of death due to tumor development and the most common type of cancer in women. ${ }^{1}$ In the USA, breast cancer is the leading type of cancer and the second most fatal cancer among female patients. ${ }^{2}$ Accumulating evidence has indicated that the risk of breast cancer is strongly related to endogenous hormone levels and genes responsive to such hormones. Recent studies have shown that the human androgen receptor (AR), which is responsive to changes in hormone levels, plays an important role in breast cancer risk. ${ }^{3}$

The human AR is a nuclear receptor. The AR gene is composed of eight exons and maps to Xq11-12. CAG repeats exist in the first exon of the AR gene, which encodes a glutamine tract. The length of this tract varies from 10 to 40 repeat units among individuals. ${ }^{3}$ The length of the CAG repeat in exon 1 of the AR might be inversely related to its transactivation efficiency. Alleles with long repeat lengths have been associated with decreased efficacy of androgenic activity, and this decreased activity will inhibit androgen signaling, which inhibits breast carcinogenesis by limiting the proliferation of breast cancer cells. ${ }^{4}$ This finding is consistent with in vitro studies, which have shown that androgen inhibits breast epithelial cell proliferation. ${ }^{5,6}$ Furthermore, recent investigations have 
indicated that polymorphisms of the AR gene are modulators of the penetrance of BRCA1 mutations in women. ${ }^{7}$

Therefore, CAG polymorphisms might be correlated with the risk of breast cancer. ${ }^{8}$ However, the results of previous studies are inconsistent. Some studies have shown that breast cancer in women exhibits an inverse association with $\mathrm{CAG}$ repeat length polymorphisms. Shorter CAG repeats have been described as high-risk factors for breast tumors. ${ }^{9-11}$ However, some studies have shown opposite results. ${ }^{12,13}$ These inconclusive and conflicting results may be partially due to relatively small sample sizes and different statistical models used in each of the published studies. Therefore, we performed a meta-analysis to evaluate the association between $\mathrm{CAG}$ repeat length polymorphisms and breast cancer risk.

\section{Methods}

\section{Data sources and searching strategy}

This meta-analysis was conducted and reported in accordance with the PRISMA (Preferred Reporting Items for Systematic Reviews and Meta-Analyses) guidelines for systematic reviews and meta-analyses (Table S1). A comprehensive search of the PubMed and EMBASE databases was conducted to identify published studies that evaluated the relationship between CAG polymorphism and breast cancer risk in women. We searched the databases using the following medical subheadings and keywords: "androgen receptor" and the abbreviation of the gene "AR", "short tandem repeat", "CAG”, "(CAG)n”, "polymorphism", and "breast cancer". Other alternative spellings were also considered. The reference lists of included papers, systematic reviews, letters, and commentaries were examined. No language restrictions were implemented.

\section{Study identification and evaluation criteria}

The relevant publications were carefully evaluated to obtain any possible related articles. The following inclusion criteria were used to select eligible studies: articles regarding AR CAG polymorphism and breast cancer risk in women; only the most recent or complete study if the same study subjects were included in more than one publication; studies with clear partial or detailed genotyping; and case-control studies using either a hospital-based or a population-based design.

\section{Data extraction}

Two authors (QM and MQ) independently extracted the following information from all qualified studies: first author's last name, publication data, population ethnicity, study design, baseline characteristics of the study population, and the genotype distribution of the cases and controls.
According to previous investigations, we defined the recessive and dominant genotypes by the length of the CAG repeat. A shorter length CAG repeat (less than 22 repeats) was defined as a recessive genotype. A long length CAG repeat (more than 22 repeats) was defined as a dominant genotype. ${ }^{6,14,15}$ Any disagreements encountered were resolved by discussion with another author (FJ) until a consensus was reached.

\section{Quality evaluation}

The Newcastle-Ottawa Scale was used to assess the quality of the included case-control studies, which evaluated three aspects of the studies including selection, comparability, and exposure. ${ }^{16}$ A study was awarded a maximum of one "star" for each high-quality item within the "selection" and "exposure" categories and a maximum of two "stars" for the "comparability" category. The quality assessment was conducted by two authors (QM and MQ) independently.

\section{Statistical analysis}

Odds ratios (ORs) and 95\% confidence intervals (CIs) were calculated to estimate the relationship between CAG polymorphism and breast cancer risk. The following comparison models were calculated: SS versus all SL-LL (SS, women carrying two shorter alleles; SL, women carrying at least one long allele; and LL, women carrying two long alleles) in all 17 studies; and a homozygote comparison (SS versus LL), recessive model (SS-SL versus LL) and dominant model (SS versus SS-LL) were performed in 12 studies, including a detailed comparison of SL and LL. Additionally, a subgroup analysis was performed based on ethnicity.

A Q-statistic test was performed to evaluate the betweenstudy heterogeneity. ${ }^{17}$ If the result of the heterogeneity test was $P<0.10$, the pooled ORs were analyzed using the random-effects model. Otherwise, the fixed-effects model was selected. These two models provided similar results when between-study heterogeneity was absent. The potential publication bias was evaluated with a funnel plot and Begg's linear regression asymmetry test. Begg's test can detect funnel plot asymmetry by determining whether the intercept deviates significantly from zero in a regression of the standardized effect estimates against their precision. ${ }^{18}$ All statistical analyses were performed using Stata version 12.0 software (Stata Corporation, College Station, TX, USA).

\section{Results \\ Search process}

Ninety-nine studies were primarily identified. The search and selection process is described in Figure 1. After an 


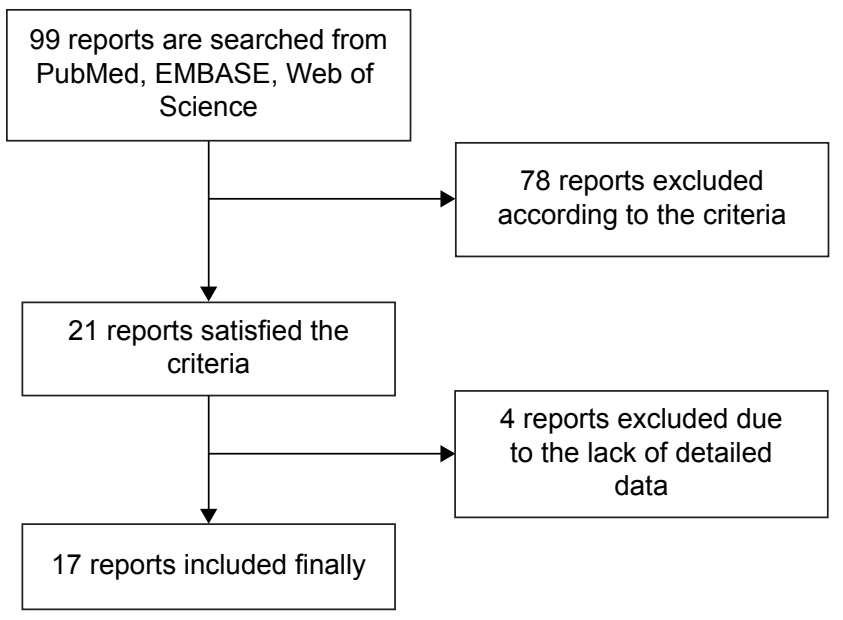

Figure I Flow diagram.

extensive literature search, we finally identified 17 reports that met our inclusion criteria and conducted at least one of the aforementioned comparisons. ${ }^{6-9-15,19-27}$

\section{Characteristics of eligible studies}

Seventeen reports were examined in this meta-analysis, which included 10,919 cases and 14,002 control subjects. The characteristics of the study population are shown in Table 1. Eleven studies were conducted among the Caucasian population, and four studies were conducted among the Asian population. Other studies were conducted among African populations. The distributions of CAG repeat lengths in alleles of the AR gene were shown in all studies. However, five studies showed only the distribution of women who carried two shorter alleles (SS) and women who carried one or two long alleles (SL-LL; Table 2).

\section{CAG polymorphism and cancer risk}

Because the $P$-value of the heterogeneity was less than 0.1 , the random effects model was selected. Seventeen studies, including 10,919 cases and 14,002 control subjects, were pooled to estimate the comparison of SS and SL-LL (D + L pooled OR 1.031, 95\% CI 0.855-1.245, $P<0.05$; Figure 2). Neither the comparison of SS versus LL nor that of SS-SL versus LL showed significant differences in breast cancer risk (D + L pooled OR 1.062, 95\% CI 0.784-1.439, $P<0.05 ; \mathrm{D}+\mathrm{L}$ pooled OR 0.994, 95\% CI 0.819-1.207; $P<0.05$ ).

Because differences in race could influence the results, we divided the studies into three groups according to ethnicity. In the Caucasian subgroup, a 1.4-fold increased risk was observed in women carrying one or two long alleles ( $\mathrm{D}+\mathrm{L}$ pooled OR 1.447, 95\% CI 1.089-1.992) in eight studies that included 8,827 cases and 11,526 control subjects (Figure 3). Additionally, compared with women who carried two shorter alleles, those with two long alleles had a substantially increased risk of breast cancer (D + L pooled OR 1.315, 95\% CI 1.014-1.707; Figure 4). These results indicate that the breast cancer risk was elevated in Caucasian women who carried one or two long alleles. However, women who carried one or two long alleles showed a protective effect against breast cancer in the Asian subgroup ( $\mathrm{D}+\mathrm{L}$ pooled OR 0.589, 95\% CI 0.307-1.129), which included three studies with 1,595 cases and 1,968 control subjects. An additional analysis was performed in the African subgroup. There were no major differences between the SS and SL-LL groups in the African subgroup (D + L pooled OR 0.962, 95\% CI 0.681-1.358), which included two studies with 497 cases and 508 control subjects. These results are presented in Table 3 .

Table I Baseline characteristics of included studies

\begin{tabular}{|c|c|c|c|c|c|c|c|c|}
\hline References & Year & Country & Ethnicity & Cases & Controls & Treatment & Mutation gene & OR $(95 \% \mathrm{Cl})$ \\
\hline Tsezou et al ${ }^{10}$ & 2008 & Greece & Caucasian & 78 & 154 & No chemotherapy or radiotherapy & AR_(CAG)n & $0.089(0.016-0.486)$ \\
\hline Wu et $\mathrm{al}^{27}$ & 2008 & $\begin{array}{l}\text { People's Republic } \\
\text { of China }\end{array}$ & Asian & 88 & 334 & No chemotherapy or radiotherapy & $A R \_(C A G) n$ & $2.70(I .00-7.3 \mid)$ \\
\hline lobagiu et al" & 2006 & France & Caucasian & 139 & 145 & No chemotherapy or radiotherapy & $A R \_(C A G) n$ & $1.93(1.05-3.55)$ \\
\hline Zheng et $\mathrm{al}^{15}$ & 2012 & USA & African & 258 & 259 & No chemotherapy or radiotherapy & $A R \_(C A G) n$ & $1.08(1.01-1.15)$ \\
\hline Dunning et $\left.a\right|^{6}$ & 1999 & UK & Caucasian & 508 & 426 & No chemotherapy or radiotherapy & $A R(C A G) n$ & $0.82(0.62-1.09)$ \\
\hline De abreu et al ${ }^{20}$ & 2007 & Brazil & Caucasian & 54 & 72 & No chemotherapy or radiotherapy & $A R \_(C A G) n$ & - \\
\hline Mehdipour et $\mathrm{a}^{23}$ & 2011 & Iran & Asian & 500 & 432 & No chemotherapy or radiotherapy & AR_(CAG)n & $2.03(1.56-2.6)$ \\
\hline Sakoda et al ${ }^{14}$ & 2011 & $\begin{array}{l}\text { People's Republic } \\
\text { of China }\end{array}$ & Asian & 614 & 879 & No chemotherapy or radiotherapy & $A R \_(C A G) n$ & $2.6(1.3-5.4)$ \\
\hline Suter et $\mathrm{a}^{26}$ & 2003 & USA & Caucasian & 524 & 461 & No chemotherapy or radiotherapy & $A R \_(C A G) n$ & $0.97(0.63-1.48)$ \\
\hline Haiman et $\mathrm{al}^{21}$ & 2002 & America & Caucasian & 727 & 960 & No chemotherapy or radiotherapy & $A R \_(C A G) n$ & $1.70(1.20-2.40)$ \\
\hline Wedren et $\mathrm{al}^{9}$ & 2007 & Finland & Caucasian & ।,496 & $\mathrm{I}, 340$ & No chemotherapy or radiotherapy & $A R \_(C A G) n$ & $1.26(1.04-1.5 \mathrm{I})$ \\
\hline Abbas et $\mathrm{al}^{19}$ & 2010 & Germany & Caucasian & 2,942 & 5,252 & No chemotherapy or radiotherapy & $A R \_(C A G) n$ & $1.10(1.03-1.18)$ \\
\hline Spurdle et $\mathrm{al}^{25}$ & 1999 & Australia & Caucasian & 368 & 284 & No chemotherapy or radiotherapy & $A R_{-}^{-}(C A G) n$ & $1.40(0.94-2.09)$ \\
\hline Liede et $\mathrm{al}^{22}$ & 2003 & Philippines & Asian & 393 & 323 & No chemotherapy or radiotherapy & $A R_{-}^{-}(C A G) n$ & $0.47(0.28-0.8)$ \\
\hline Wang et $\mathrm{al}^{13}$ & 2005 & USA & African & 239 & 249 & No chemotherapy or radiotherapy & $A R \_(C A G) n$ & $3.18(1.08-9.36)$ \\
\hline Slattery et $\mathrm{a}^{24}$ & 2007 & USA & Caucasian & 1,734 & 2,039 & No chemotherapy or radiotherapy & $A R \_(C A G) n$ & $0.87(0.62-1.23)$ \\
\hline Gonzalez et al ${ }^{12}$ & 2007 & Spain & Caucasian & 257 & 393 & No chemotherapy or radiotherapy & $A R \_(C A G) n$ & $1.49(1.06-2.09)$ \\
\hline
\end{tabular}

Abbreviations: $\mathrm{OR}$, odds ratio; $\mathrm{Cl}$, confidence interval. 
Table 2 Distribution of androgen receptor alleles

\begin{tabular}{|c|c|c|c|c|c|c|c|}
\hline References & Ethnicity & SS (case) & SL (case) & LL (case) & SS (control) & SL (control) & LL (control) \\
\hline De abreu et $\mathrm{a}^{20}$ & Caucasian & 36 & II & 7 & 20 & 39 & 13 \\
\hline Tsezou et a $\left.\right|^{10}$ & Caucasian & 51 & 24 & 3 & 31 & 77 & 46 \\
\hline Wu et $\mathrm{al}^{27}$ & Asian & 16 & 51 & 21 & 92 & 159 & 83 \\
\hline lobagiu et al" & Caucasian & 35 & 72 & 32 & 30 & 66 & 49 \\
\hline Zheng et al ${ }^{15}$ & African & 124 & 102 & 32 & 127 & 110 & 22 \\
\hline Dunning et $\mathrm{a}^{6}$ & Caucasian & 84 & 215 & 209 & 54 & 212 & 160 \\
\hline Mehdipour et $\mathrm{a}^{23}$ & Asian & 130 & 228 & 142 & 210 & 164 & 58 \\
\hline Sakoda et al ${ }^{14}$ & Asian & 50 & 248 & 316 & 74 & 366 & 439 \\
\hline Suter et $\mathrm{a}^{26}$ & Caucasian & 121 & 255 & 148 & 122 & 206 & 133 \\
\hline Haiman et $\mathrm{al}^{21}$ & Caucasian & 179 & 374 & 174 & 247 & 481 & 232 \\
\hline Wedren et $\mathrm{al}^{9}$ & Caucasian & 376 & 698 & 422 & 301 & 651 & 388 \\
\hline Abbas et al ${ }^{19}$ & Caucasian & 736 & I,489 & 717 & I,291 & 2,526 & I,435 \\
\hline Spurdle et $\mathrm{a}^{25}$ & Caucasian & 78 & 290 & & 71 & 213 & \\
\hline Liede et $\mathrm{a}^{22}$ & Asian & 178 & 215 & & 152 & $17 \mid$ & \\
\hline Wang et $\mathrm{al}^{13}$ & African & 145 & 94 & & 156 & 93 & \\
\hline Slattery et $\mathrm{al}^{24}$ & Caucasian & 400 & $\mathrm{I}, 334$ & & 464 & $\mathrm{I}, 575$ & \\
\hline Gonzalez et al ${ }^{12}$ & Caucasian & 155 & 102 & & 270 & 123 & \\
\hline
\end{tabular}

Notes: SS, women carrying two shorter alleles; SL, women carrying at least one long allele; LL, women carrying two long alleles.

\section{Heterogeneity}

Obvious heterogeneity was detected in each of the comparison models. A meta-regression revealed that ethnicity, publication year, sample size, and source of control subjects did not contribute to the heterogeneity (data not shown).

\section{Publication bias}

To assess the publication bias, a funnel plot and Begg's test were performed. No publication bias was detected in the overall analysis (Figure 5). Additionally, no publication bias was found in the Caucasian and Asian subgroup analyses

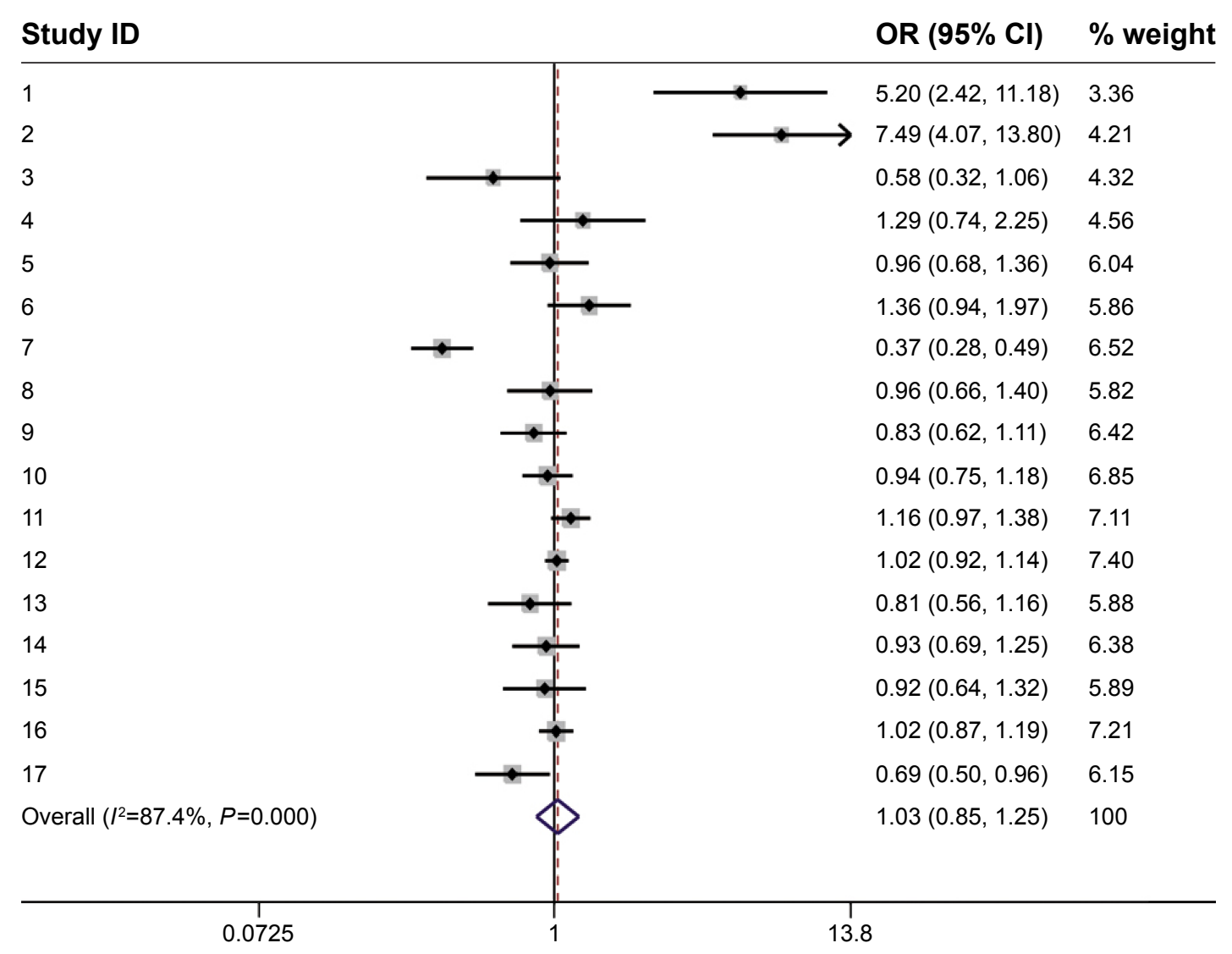

Figure 2 (Continued) 


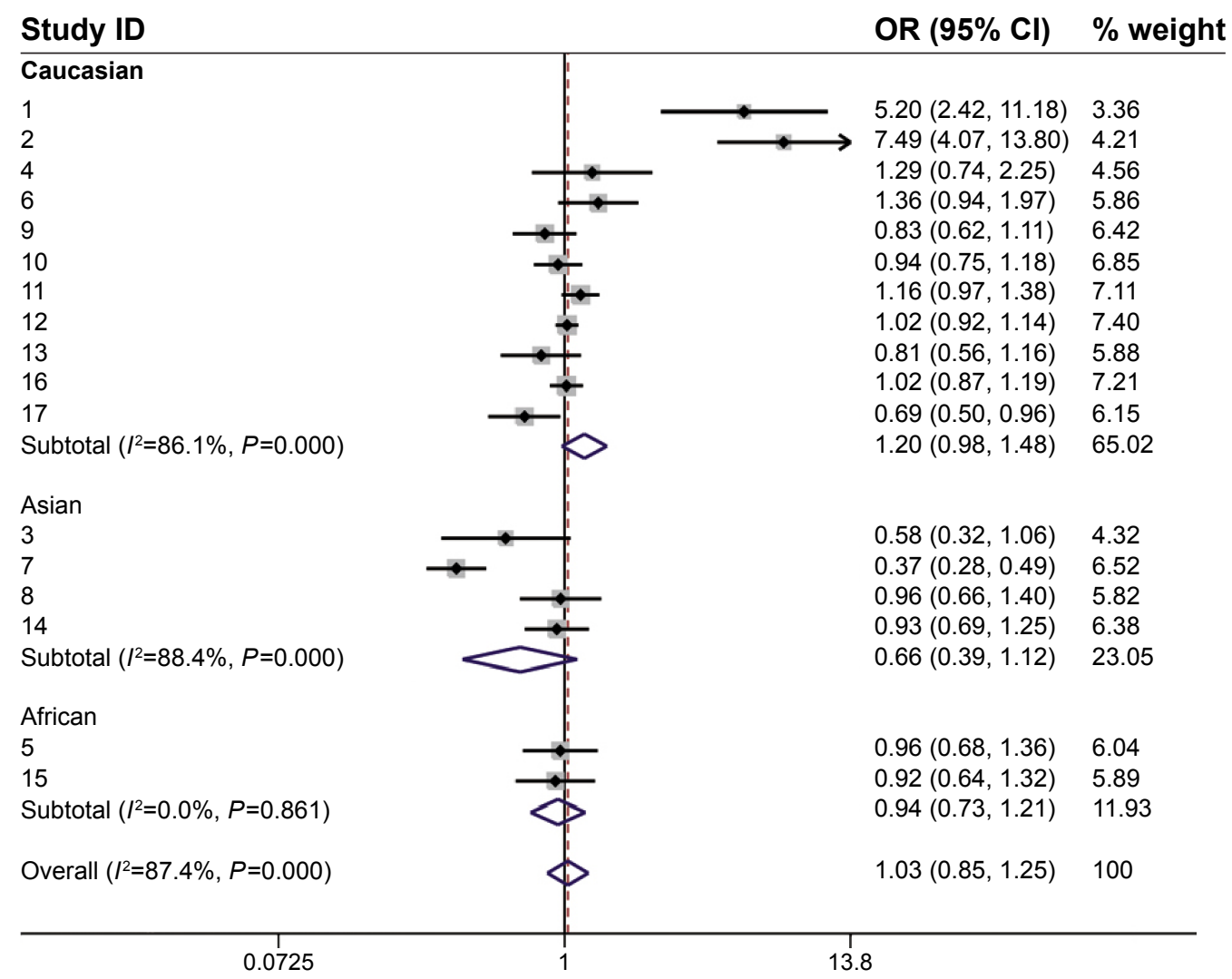

Figure 2 Forest plot of SS versus all SL-LL and Forest plot of the subgroup analysis (SS versus all SL-LL).

Notes: Weights are from random effects analysis; SS, women carrying two shorter alleles; SL, women carrying at least one long allele; LL, women carrying two long alleles. Abbreviations: $\mathrm{OR}$, odds ratio; $\mathrm{Cl}$, confidence interval.

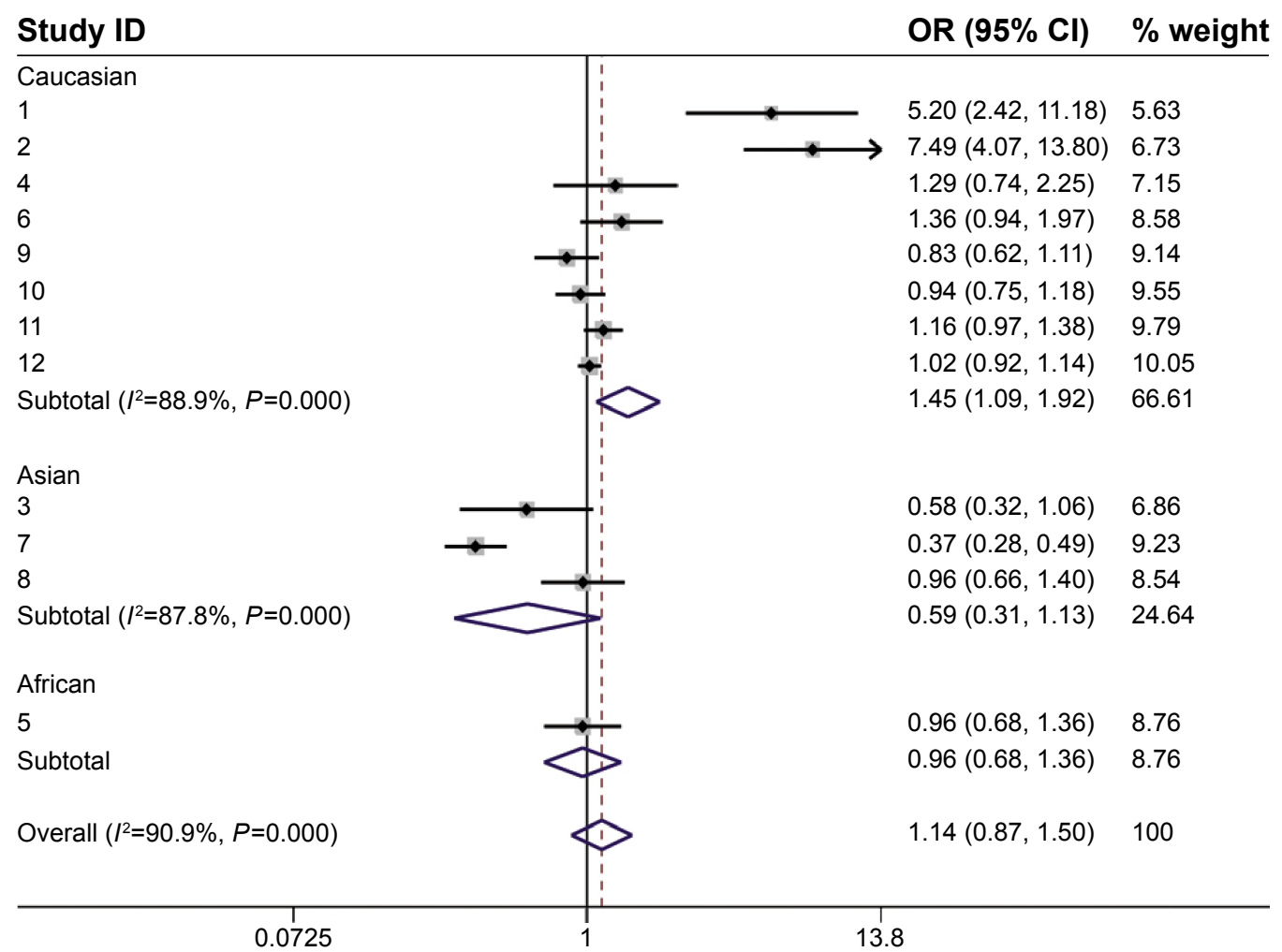

Figure 3 Forest plot of the subgroup analysis (SS versus SL-LL).

Notes: Weights are from random effects analysis; SS, women carrying two shorter alleles; SL, women carrying at least one long allele; LL, women carrying two long alleles. Abbreviations: $\mathrm{OR}$, odds ratio; $\mathrm{Cl}$, confidence interval. 


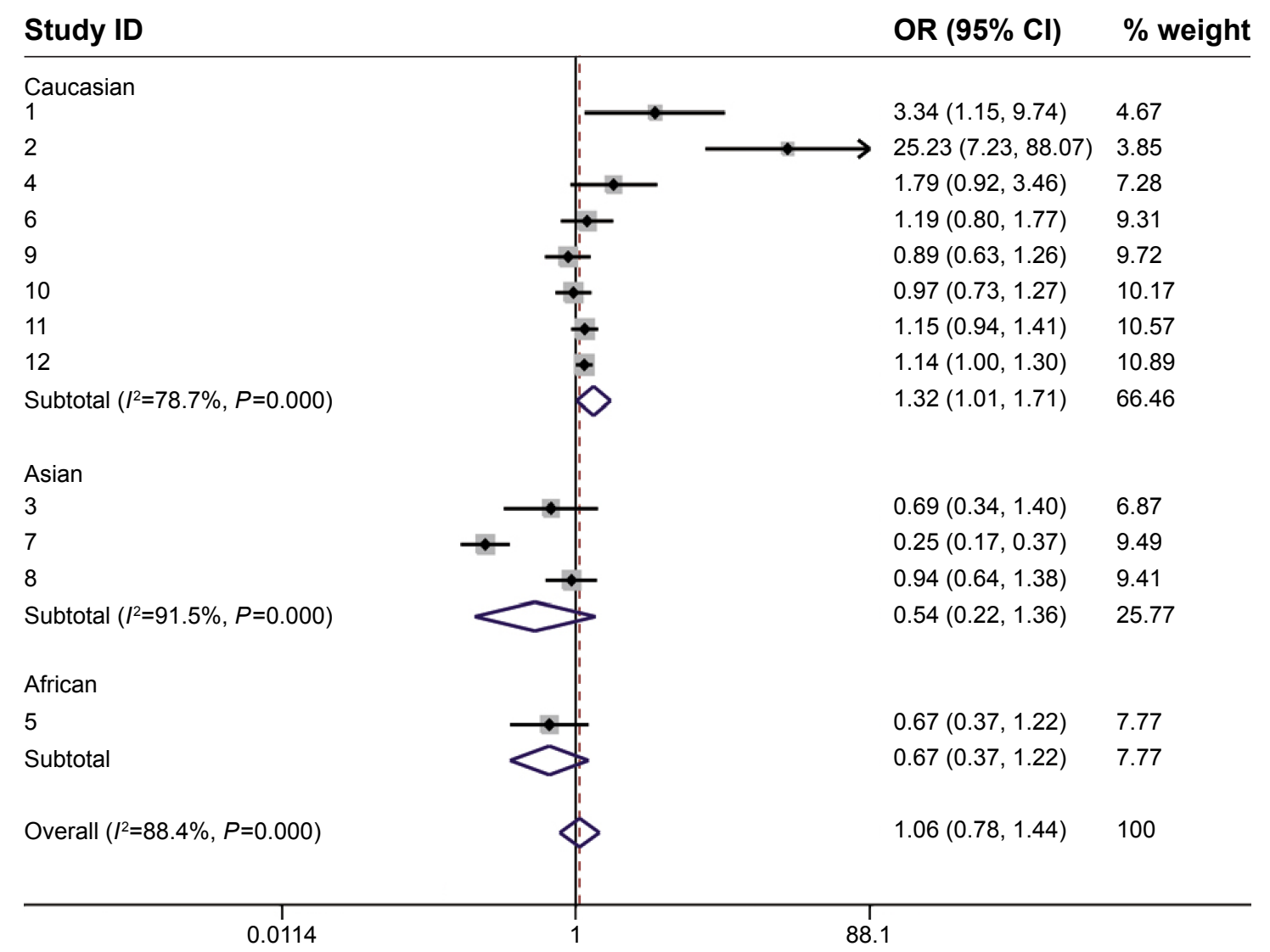

Figure 4 Forest plot of the subgroup analysis (SS versus LL).

Notes: Weights are from random effects analysis; SS, women carrying two shorter alleles; SL, women carrying at least one long allele; LL, women carrying two long alleles.

$\left(P_{\text {Caucasian }}=0.072\right.$ and $\left.P_{\text {Asian }}=0.656\right)$. Two studies showed Hardy-Weinberg disequilibrium. ${ }^{11,26}$

\section{Discussion}

Breast cancer is a known sex steroid hormone-related disease. Sex steroid hormones exert their biological effects by binding to nuclear receptors, including the AR. The AR mediates the effects of androgen and plays a complex role in breast carcinogenesis. Androgen binding to the AR activates the androgen signaling pathway and inhibits the proliferation of breast cancer. ${ }^{3}$ Polymorphic variations in sex hormone receptor-encoding genes, such as CAG polymorphisms in the AR, may therefore alter the activity of the receptor molecules and, in turn, the susceptibility to breast cancer. ${ }^{28-31}$

Previous conclusions regarding CAG polymorphism and breast cancer risk have been conflicting and inconsistent. Gonzalez et al, ${ }^{12}$ Liede et $\mathrm{al}^{22}$ and Wang et $\mathrm{al}^{13}$ proposed that a long CAG allele would increase the risk of breast cancer, and a study by Haiman et $\mathrm{al}^{21}$ demonstrated that long AR repeat alleles might increase the breast cancer risk among women with a first-degree

Table 3 Meta-analysis results regarding the length of CAG repeats and breast cancer risk

\begin{tabular}{|c|c|c|c|c|c|c|c|c|c|c|c|c|}
\hline & \multicolumn{3}{|c|}{$\begin{array}{l}\text { Comparison } \\
\text { (SS versus any SL-LL) }\end{array}$} & \multicolumn{3}{|c|}{$\begin{array}{l}\text { Homozygote comparison } \\
\text { (SS versus LL) }\end{array}$} & \multicolumn{3}{|c|}{$\begin{array}{l}\text { Recessive model } \\
\text { (SS-SL versus LL) }\end{array}$} & \multicolumn{3}{|c|}{$\begin{array}{l}\text { Dominant model } \\
\text { (SS versus SL-LL) }\end{array}$} \\
\hline & Studies & OR $(95 \% \mathrm{CI})$ & $P_{\text {het }}$ & Studies & OR (95\% CI) & $P_{\text {het }}$ & Studies & OR $(95 \% \mathrm{CI})$ & $P_{\text {het }}$ & Studies & OR (95\% CI) & $P_{\text {het }}$ \\
\hline Overall & 17 & $\begin{array}{l}\text { I.03। } \\
(0.855-1.245)\end{array}$ & $<0.01$ & 12 & $\begin{array}{l}1.062 \\
(0.784-1.439)\end{array}$ & $<0.01$ & 12 & $\begin{array}{l}0.994 \\
(0.819-1.207)\end{array}$ & $<0.01$ & 12 & $\begin{array}{l}\mathrm{I} .142 \\
(0.87 \mathrm{I}-\mathrm{I} .498)\end{array}$ & $<0.01$ \\
\hline Caucasian & II & $\begin{array}{l}1.201 \\
(0.977-1.477)\end{array}$ & $<0.01$ & 8 & $\begin{array}{l}1.315 \\
(1.014-1.707)^{*}\end{array}$ & $<0.01$ & 8 & $\begin{array}{l}\text { I.126 } \\
(0.948-1.338)\end{array}$ & $<0.01$ & 8 & $\begin{array}{l}1.447 \\
(1.089-1.992)^{*}\end{array}$ & $<0.01$ \\
\hline Asian & 4 & $\begin{array}{l}0.665 \\
(0.393-1.124)\end{array}$ & $<0.01$ & 3 & $\begin{array}{l}0.540 \\
(0.215-1.357)\end{array}$ & $<0.01$ & 3 & $\begin{array}{l}0.721 \\
(0.384-1.352)\end{array}$ & $<0.01$ & 3 & $\begin{array}{l}0.589 \\
(0.307-1.129)\end{array}$ & $<0.01$ \\
\hline African & 2 & $\begin{array}{l}0.942 \\
(0.733-1.210)\end{array}$ & 0.861 & 2 & $\begin{array}{l}0.671 \\
(0.370-1.219)\end{array}$ & - & 2 & $\begin{array}{l}0.656 \\
(0.370-1.162)\end{array}$ & - & 2 & $\begin{array}{l}0.962 \\
(0.68 I-1.358)\end{array}$ & - \\
\hline
\end{tabular}

Notes: $P_{\text {het' }}, P$-value of heterogeneity; *significant difference; SS, women carrying two shorter alleles; SL, women carrying at least one long allele; LL, women carrying two long alleles.

Abbreviations: OR, odds radio; $\mathrm{Cl}$, confidence interval. 


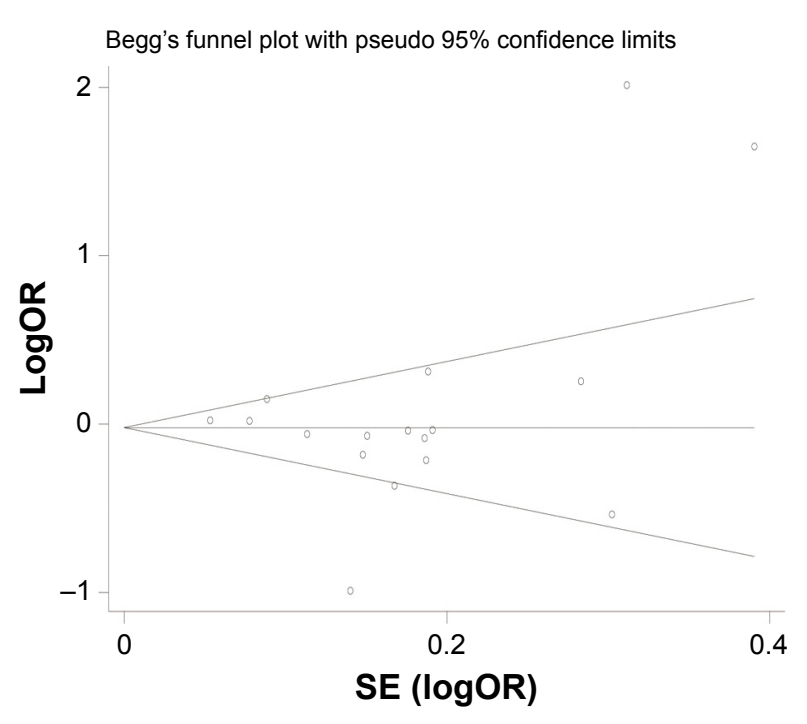

Figure 5 Begg's test for publication bias.

Abbreviation: SE (logOR), standard error for log odds ratio.

family history of breast cancer. However, no associations were found in studies by Slattery et $\mathrm{al}^{24}$ or Spurdle et al..$^{25}$ In contrast, some investigations have shown that short CAG repeats are associated with breast carcinoma in women. ${ }^{9,10}$

In the present meta-analysis, we found that $\mathrm{CAG}$ repeats longer than 22 units increased the risk of breast cancer in Caucasian women (SL-LL versus SS, OR 1.447, 95\% CI 1.089-1.992). An increased breast cancer risk was also found in Caucasian women in the homozygote comparison model (SS versus LL, OR 1.315, 95\% CI 1.014-1.707).

In a meta-analysis conducted by Hao et al 4 years ago, ${ }^{32}$ long CAG repeats had a protective effect on breast cancer in the dominant comparison. However, many studies have been published in the past 4 years, and more studies have investigated the Asian and African populations. Thus, different and comprehensive conclusions are presented in this meta-analysis. Initially, we considered that long CAG repeats might increase the susceptibility to breast cancer in Caucasian women. However, we analyzed the data from all investigations collected in this meta-analysis. The outcome showed no association between CAG polymorphisms and breast cancer in women; this result differs from that of a previous meta-analysis. Taking ethnic differences into consideration, we conducted a subgroup analysis by race. In the Caucasian subgroup, a significant correlation was observed between CAG polymorphisms and breast cancer risk. These results were consistent with the conclusions of Gonzalez et al and Wang et al. Androgen might play a protective role in breast cancer development. ${ }^{12}$ Long CAG repeats were correlated with decreased efficacy in inducing androgen activity. Long CAG repeats could contribute to the risk of breast cancer in women by decreasing the AR transcriptional efficiency in breast cells and hence producing a decreased response to circulating androgens. Conversely, there was a different trend in the Asian subgroup. The long CAG repeat polymorphisms showed a trend of reducing the risk of breast cancer in women. However, strictly speaking, no statistically significant correlation was identified for $\mathrm{CAG}$ repeat length in the Asian population because the upper limit of the $95 \%$ CI was greater than 1 . This opposite trend might result from many factors. The variation ranges of CAG repeats in the Asian population were shorter than those in the Caucasian population. Thus, the median of the CAG repeat length might be different in the Asian population than the Caucasian population. This discrepancy between races might have led to the inconsistent results. Moreover, only three studies included a subgroup analysis of the Asian population. The sample size was too small. More studies are needed to determine the correlation between the CAG polymorphism length and breast cancer in the Asian population. There was no positive result in the African subgroup.

As mentioned previously, the heterogeneity of this metaanalysis was not satisfactory. After dividing the subjects into three subgroups, heterogeneity still existed. A metaregression was necessary to identify the heterogeneity. We analyzed the ethnicity, source of control subjects, publication year, study type, age of the population and official language of the population. The results of the official language analysis suggested that the heterogeneity of the OR was derived from studies by Tsezou et al, ${ }^{10}$ Mehdipour et al ${ }^{23}$ and De Abreu et al. ${ }^{20}$ We then reviewed the articles again, and we found no obvious difference in the populations in these three articles and those in the other studies. Therefore, we propose that the heterogeneity of the OR may be derived from other factors that were not mentioned in the studies.

The strengths of our study include a large sample size and no indication of publication bias. However, some limitations should be considered. Physiological factors, environmental factors and other unknown risks may play a role in the interaction of AR genetic variations and breast cancer risk in women. ${ }^{33-36}$ Moreover, due to a relatively small sample size or lack of necessary information in some studies, we were unable to perform further subgroup analyses. Thus, further investigations should be performed to identify the association between the length of CAG repeat polymorphisms and breast cancer in women.

\section{Conclusion}

In this meta-analysis, we reviewed previous findings regarding the association between AR CAG repeat polymorphisms and breast cancer risk. We discovered that long CAG 
repeats might increase the susceptibility to breast cancer in the Caucasian population. Further studies are required to analyze the relationship between the length of CAG repeat polymorphisms and breast cancer in women.

\section{Acknowledgments}

This work was supported by the National Natural Science Foundation of China (grant 81472702), Natural Science Foundation of Jiangsu Province (grant BK2012482), and Jiangsu Provincial Special Program of Medical Science (grant BL2012030).

\section{Disclosure}

The authors declare that they have no conflicts of interest in this work.

\section{References}

1. Wiseman RA. Breast cancer hypothesis: a single cause for the majority of cases. J Epidemiol Community Health. 2000;54:851-858.

2. Siegel R, Naishadham D, Jemal A. Cancer statistics, 2012. CA Cancer J Clin. 2012;62:10-29.

3. Giguere Y, Dewailly E, Brisson J, et al. Short polyglutamine tracts in the androgen receptor are protective against breast cancer in the general population. Cancer Res. 2001;61:5869-5874.

4. Given HF, Radbourne R, Oag H, et al. The androgen receptor exon 1 trinucleotide repeat does not act as a modifier of the age of presentation in breast cancer. Eur J Cancer. 2000;36:533-534.

5. Dagan E, Friedman E, Paperna T, Carmi N, Gershoni-Baruch R. Androgen receptor CAG repeat length in Jewish Israeli women who are BRCA1/2 mutation carriers: association with breast/ovarian cancer phenotype. Eur J Hum Genet. 2002;10:724-728.

6. Dunning AM, McBride S, Gregory J, et al. No association between androgen or vitamin D receptor gene polymorphisms and risk of breast cancer. Carcinogenesis. 1999;20:2131-2135.

7. Rajender S, Francis A, Pooja S, et al. CAG repeat length polymorphism in the androgen receptor gene and breast cancer risk: data on Indian women and survey from the world. Breast Cancer Res Treat. 2011;127: $751-760$.

8. Rebbeck TR, Kantoff PW, Krithivas K, et al. Modification of BRCA1associated breast cancer risk by the polymorphic androgen-receptor CAG repeat. Am J Hum Genet. 1999;64:1371-1377.

9. Wedren S, Magnusson C, Humphreys K, et al. Associations between androgen and vitamin $\mathrm{D}$ receptor microsatellites and postmenopausal breast cancer. Cancer Epidemiol Biomarkers Prev. 2007;16: $1775-1783$.

10. Tsezou A, Tzetis M, Gennatas C, et al. Association of repeat polymorphisms in the estrogen receptors alpha, beta (ESR1, ESR2) and androgen receptor (AR) genes with the occurrence of breast cancer. Breast. 2008;17:159-166.

11. Iobagiu C, Lambert C, Normand M, Genin C. Microsatellite profile in hormonal receptor genes associated with breast cancer. Breast Cancer Res Treat. 2006;95:153-159.

12. Gonzalez A, Javier Dorta F, Rodriguez G, et al. Increased risk of breast cancer in women bearing a combination of large CAG and GGN repeats in the exon 1 of the androgen receptor gene. Eur J Cancer. 2007;43: 2373-2380.

13. Wang W, John EM, Ingles SA. Androgen receptor and prostate-specific antigen gene polymorphisms and breast cancer in African-American women. Cancer Epidemiol Biomarkers Prev. 2005;14:2990-2994.

14. Sakoda LC, Blackston CR, Doherty JA, et al. Selected estrogen receptor 1 and androgen receptor gene polymorphisms in relation to risk of breast cancer and fibrocystic breast conditions among Chinese women. Cancer Epidemiol. 2011;35:48-55.
15. Zheng Y, Huo D, Zhang J, Yoshimatsu TF, Niu Q, Olopade OI. Microsatellites in the estrogen receptor (ESR1, ESR2) and androgen receptor (AR) genes and breast cancer risk in African American and Nigerian women. PLoS One. 2012;7:e40494.

16. Cota GF, de Sousa MR, Fereguetti TO, Rabello A. Efficacy of anti-leishmania therapy in visceral leishmaniasis among HIV infected patients: a systematic review with indirect comparison. PLoS Negl Trop Dis. 2013;7:e2195.

17. Lau J, Ioannidis JP, Schmid CH. Quantitative synthesis in systematic reviews. Ann Intern Med. 1997;127:820-826.

18. Egger M, Davey Smith G, Schneider M, Minder C. Bias in meta-analysis detected by a simple, graphical test. BMJ. 1997;315:629-634.

19. MARIE-GENICA Consortium on Genetic Susceptibility for Menopausal Hormone Therapy Related Breast Cancer Risk. Polymorphisms in genes of the steroid receptor superfamily modify postmenopausal breast cancer risk associated with menopausal hormone therapy. Int $J$ Cancer. 2010;126:2935-2946.

20. De Abreu FB, Pirolo LJ, Canevari Rde A, et al. Shorter CAG repeat in the AR gene is associated with atypical hyperplasia and breast carcinoma. Anticancer Res. 2007;27:1199-1205.

21. Haiman CA, Brown M, Hankinson SE, et al. The androgen receptor CAG repeat polymorphism and risk of breast cancer in the Nurses' Health Study. Cancer Res. 2002;62:1045-1049.

22. Liede A, Zhang W, De Leon Matsuda ML, Tan A, Narod SA. Androgen receptor gene polymorphism and breast cancer susceptibility in The Philippines. Cancer Epidemiol Biomarkers Prev. 2003;12:848-852.

23. Mehdipour P, Pirouzpanah S, Kheirollahi M, Atri M. Androgen receptor gene $\mathrm{CAG}$ repeat polymorphism and breast cancer risk in Iranian women: a case-control study. Breast J. 2011;17:39-46.

24. Slattery ML, Sweeney C, Herrick J, et al. ESR1, AR, body size, and breast cancer risk in Hispanic and non-Hispanic white women living in the Southwestern United States. Breast Cancer Res Treat. 2007;105:327-335.

25. Spurdle AB, Dite GS, Chen X, et al. Androgen receptor exon 1 CAG repeat length and breast cancer in women before age forty years. $J$ Natl Cancer Inst. 1999;91:961-966.

26. Suter NM, Malone KE, Daling JR, Doody DR, Ostrander EA. Androgen receptor (CAG)n and (GGC)n polymorphisms and breast cancer risk in a population-based case-control study of young women. Cancer Epidemiol Biomarkers Prev. 2003;12:127-135.

27. Wu MH, Chou YC, Yu CP, et al. Androgen receptor gene CAG repeats, estrogen exposure status, and breast cancer susceptibility. Eur J Cancer Prev. 2008;17:317-322.

28. Gottlieb B, Alvarado C, Wang C, et al. Making sense of intratumor genetic heterogeneity: altered frequency of androgen receptor CAG repeat length variants in breast cancer tissues. Hum Mutat. 2013;34:610-618.

29. Azrak S, Ayyasamy V, Zirpoli G, et al. CAG repeat variants in the POLG1 gene encoding mtDNA polymerase-gamma and risk of breast cancer in African-American women. PLoS One. 2012;7:e29548.

30. Russo J, Russo IH. Genotoxicity of steroidal estrogens. Trends Endocrinol Metab. 2004;15:211-214.

31. Gao X, Loggie BW, Nawaz Z. The roles of sex steroid receptor coregulators in cancer. Mol Cancer. 2002;1:7.

32. Hao Y, Montiel R, Li B, Huang E, Zeng L, Huang Y. Association between androgen receptor gene $\mathrm{CAG}$ repeat polymorphism and breast cancer risk: a meta-analysis. Breast Cancer Research and Treatment. 2010;124:815-820.

33. Maggiolini M, Donze O, Jeannin E, Ando S, Picard D. Adrenal androgens stimulate the proliferation of breast cancer cells as direct activators of estrogen receptor alpha. Cancer Res. 1999;59:4864-4869.

34. Holm M, Olsen A, Kroman N, Tjonneland A. Lifestyle influences on the association between pre-diagnostic hormone replacement therapy and breast cancer prognosis - results from The Danish 'Diet, Cancer and Health' prospective cohort. Maturitas. 2014;79:442-448.

35. Xi J, Su Y, Fadiel AB, et al. Association of physical activity and polymorphisms in FGFR2 and DNA methylation related genes with breast cancer risk. Cancer Epidemiol. 2014;38:708-714.

36. Rabstein S, Harth V, Justenhoven C, et al. Polymorphisms in circadian genes, night work and breast cancer: results from the GENICA study. Chronobiol Int. 2014;31:1115-1122. 


\section{Supplementary material}

Table SI PRISMA checklist

\begin{tabular}{|c|c|c|c|}
\hline Section & \# & Check item & $\begin{array}{l}\text { Reported } \\
\text { on page }\end{array}$ \\
\hline \multicolumn{4}{|l|}{ Title } \\
\hline Title & I & Identify the report as a systematic review, meta-analysis, or both. & I \\
\hline \multicolumn{4}{|c|}{ 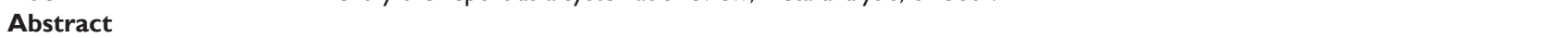 } \\
\hline $\begin{array}{l}\text { Structured } \\
\text { summary }\end{array}$ & 2 & $\begin{array}{l}\text { Provide a structured summary including, as applicable: background; objectives; data sources; study } \\
\text { eligibility criteria, participants, and interventions; study appraisal and synthesis methods; results; } \\
\text { limitations; conclusions and implications of key findings; systematic review registration number. }\end{array}$ & 2 \\
\hline \multicolumn{4}{|l|}{ Introduction } \\
\hline Rationale & 3 & Describe the rationale for the review in the context of what is already known. & 3 \\
\hline Objectives & 4 & $\begin{array}{l}\text { Provide an explicit statement of questions being addressed with reference to participants, interventions, } \\
\text { comparisons, outcomes, and study design (PICOS). }\end{array}$ & 3 \\
\hline \multicolumn{4}{|c|}{ 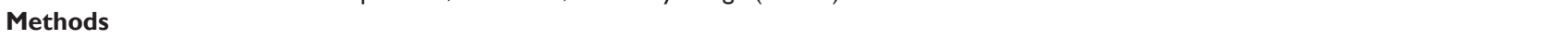 } \\
\hline $\begin{array}{l}\text { Protocol and } \\
\text { registration }\end{array}$ & 5 & $\begin{array}{l}\text { Indicate if a review protocol exists, if and where it can be accessed (eg, Web address), and, if available, } \\
\text { provide registration information including registration number. }\end{array}$ & $3-4$ \\
\hline Eligibility criteria & 6 & $\begin{array}{l}\text { Specify study characteristics (eg, PICOS, length of follow-up) and report characteristics (eg, years } \\
\text { considered, language, publication status) used as criteria for eligibility, giving rationale. }\end{array}$ & 4 \\
\hline $\begin{array}{l}\text { Information } \\
\text { sources }\end{array}$ & 7 & $\begin{array}{l}\text { Describe all information sources (eg, databases with dates of coverage, contact with study authors to } \\
\text { identify additional studies) in the search and date last searched. }\end{array}$ & 4 \\
\hline Search & 8 & $\begin{array}{l}\text { Present full electronic search strategy for at least one database, including any limits used, such that it } \\
\text { could be repeated. }\end{array}$ & 4 \\
\hline Study selection & 9 & $\begin{array}{l}\text { State the process for selecting studies (ie, screening, eligibility, included in systematic review, and, if } \\
\text { applicable, included in the meta-analysis). }\end{array}$ & 4 \\
\hline $\begin{array}{l}\text { Data collection } \\
\text { process }\end{array}$ & 10 & $\begin{array}{l}\text { Describe method of data extraction from reports (eg, piloted forms, independently, in duplicate) and any } \\
\text { processes for obtaining and confirming data from investigators. }\end{array}$ & 4 \\
\hline Data items & 11 & $\begin{array}{l}\text { List and define all variables for which data were sought (eg, PICOS, funding sources) and any assumptions } \\
\text { and simplifications made. }\end{array}$ & 4 \\
\hline $\begin{array}{l}\text { Risk of bias in } \\
\text { individual } \\
\text { studies }\end{array}$ & 12 & $\begin{array}{l}\text { Describe methods used for assessing risk of bias of individual studies (including specification of whether } \\
\text { this was done at the study or outcome level), and how this information is to be used in any data synthesis. }\end{array}$ & 4 \\
\hline Summary measures & 13 & State the principal summary measures (eg, risk ratio, difference in means). & 4 \\
\hline Synthesis of results & 14 & $\begin{array}{l}\text { Describe the methods of handling data and combining results of studies, if done, including measures of } \\
\text { consistency (eg, 12) for each meta-analysis. }\end{array}$ & $4-5$ \\
\hline $\begin{array}{l}\text { Risk of bias across } \\
\text { studies }\end{array}$ & 15 & $\begin{array}{l}\text { Specify any assessment of risk of bias that may affect the cumulative evidence (eg, publication bias, } \\
\text { selective reporting within studies). }\end{array}$ & 5 \\
\hline Additional analyses & 16 & $\begin{array}{l}\text { Describe methods of additional analyses (eg, sensitivity or subgroup analyses, meta-regression), if done, } \\
\text { indicating which were pre-specified. }\end{array}$ & 5 \\
\hline \multicolumn{4}{|c|}{ 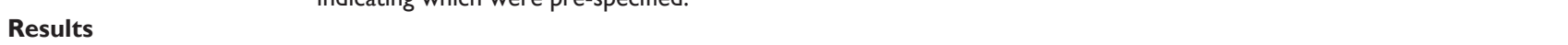 } \\
\hline Study selection & 17 & $\begin{array}{l}\text { Give numbers of studies screened, assessed for eligibility, and included in the review, with reasons for } \\
\text { exclusions at each stage, ideally with a flow diagram. }\end{array}$ & 5 \\
\hline $\begin{array}{l}\text { Study } \\
\text { characteristics }\end{array}$ & 18 & $\begin{array}{l}\text { For each study, present characteristics for which data were extracted (eg, study size, PICOS, follow-up } \\
\text { period) and provide the citations. }\end{array}$ & 5 \\
\hline $\begin{array}{l}\text { Risk of bias within } \\
\text { studies }\end{array}$ & 19 & Present data on risk of bias of each study and, if available, any outcome level assessment (see item 12). & 5 \\
\hline $\begin{array}{l}\text { Results of } \\
\text { individual studies }\end{array}$ & 20 & $\begin{array}{l}\text { For all outcomes considered (benefits or harms), present, for each study: (a) simple summary data for } \\
\text { each intervention group (b) effect estimates and confidence intervals, ideally with a forest plot. }\end{array}$ & 5 \\
\hline Synthesis of results & 21 & Present results of each meta-analysis done, including confidence intervals and measures of consistency. & $5-6$ \\
\hline $\begin{array}{l}\text { Risk of bias across } \\
\text { studies }\end{array}$ & 22 & Present results of any assessment of risk of bias across studies (see item 15). & 6 \\
\hline $\begin{array}{l}\text { Additional analysis } \\
\text { Discussion }\end{array}$ & 23 & Give results of additional analyses, if done (eg, sensitivity or subgroup analyses, meta-regression [see item 16]). & 6 \\
\hline $\begin{array}{l}\text { Summary of } \\
\text { evidence }\end{array}$ & 24 & $\begin{array}{l}\text { Summarize the main findings including the strength of evidence for each main outcome; consider their } \\
\text { relevance to key groups (eg, health care providers, users, and policy makers). }\end{array}$ & 6 \\
\hline Limitations & 25 & $\begin{array}{l}\text { Discuss limitations at study and outcome level (eg, risk of bias), and at review-level (eg, incomplete } \\
\text { retrieval of identified research, reporting bias). }\end{array}$ & 7 \\
\hline Conclusions & 26 & $\begin{array}{l}\text { Provide a general interpretation of the results in the context of other evidence, and implications for } \\
\text { future research. }\end{array}$ & 8 \\
\hline \multicolumn{4}{|l|}{ Funding } \\
\hline Funding & 27 & $\begin{array}{l}\text { Describe sources of funding for the systematic review and other support (eg, supply of data); role of } \\
\text { funders for the systematic review. }\end{array}$ & 8 \\
\hline
\end{tabular}

Abbreviations: PRISMA, Preferred Reporting Items for Systematic Reviews and Meta-Analyses; PICOS, participants, interventions, comparators, outcomes, and study design. 


\section{Publish your work in this journal}

OncoTargets and Therapy is an international, peer-reviewed, open access journal focusing on the pathological basis of all cancers, potential targets for therapy and treatment protocols employed to improve the management of cancer patients. The journal also focuses on the impact of management programs and new therapeutic agents and protocols on

patient perspectives such as quality of life, adherence and satisfaction. The manuscript management system is completely online and includes a very quick and fair peer-review system, which is all easy to use. Visit http://www.dovepress.com/testimonials.php to read real quotes from published authors.

Submit your manuscript here: http://www.dovepress.com/oncotargets-and-therapy-journal 